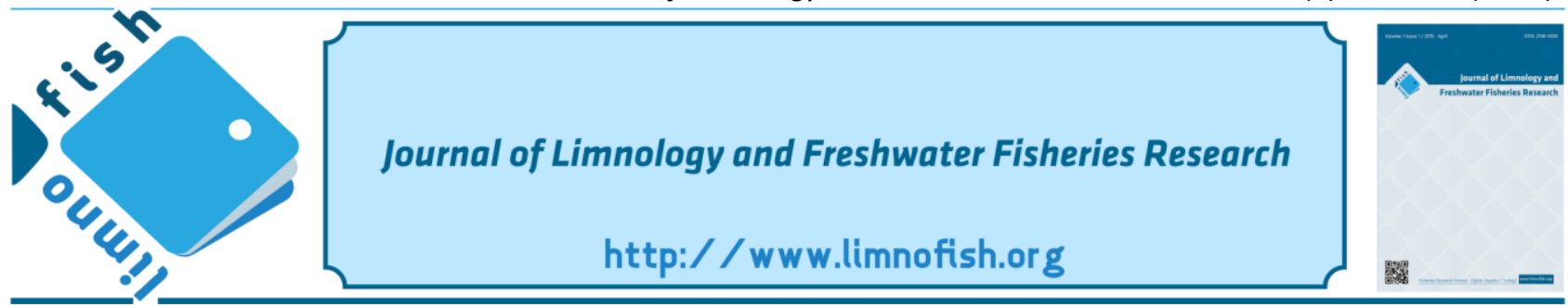

\title{
Determination of Bacterial Contamination and Antibiotic Resistance of the Bacteria in the Some Trout Farm Hatcheries in the Eastern Black Sea Region of Turkey
}

\author{
Şevki KAYIŞ ${ }^{1^{*}(D)}$, Gökhan SOYKÖSE ${ }^{1}$ (D), Zeynep Zehra İPEK ${ }^{1}$ (i), Akif ER ${ }^{1}$ \\ ${ }^{1}$ Recep Tayyip Erdoğan University, Fisheries Faculty 53100-Rize
}

\section{A B STRACT}

This study was carried out to reveal bacterial contamination and antibiotic resistance profiles of isolated bacteria in the hatchery systems of trout farms located in the Eastern Black Sea region of Turkey. Inlet water, egg, alevin and fry samples of 11 different trout farms were examined in terms of bacterial contamination in four different basins. After sampling, isolated bacteria were identified by making phenotypic and genotypic analyses. The majority of a total of 43 strains belongs to the genera Aeromonas and Pseudomonas, but also Lelliottia sp., Bacillus sp. and Lactococcus lactis were isolated from hatchery systems. Considering all basins, except for the 2nd basin, the highest antibiotic resistance of bacteria was against Ampicillin. The lowest antibiotic resistance percentages were determined against gentamicin and enrofloxacin. As a result of the research, the detection of different bacteria in the samples taken from the inlet water of fish farms showed presence of different bacteria contaminating the hatchery water. It thereby stressed the need for improved hygiene measures in these farms.

Keywords: Antibiotic, bacteria, trout, hatchery

\section{ARTICLE INFO}

\section{RESEARCH ARTICLE}

Received : 18.11 .2020

Revised : : 15.12.2020

Accepted : : 17.12.2020

Published :26.08.2021

DOI:10.17216/LimnoFish.827718

\section{* CORRESPONDING AUTHOR}

sevki.kayis@erdogan.edu.tr

Phone : +904642233385

Türkiye'nin Doğu Karadeniz Bölgesinde Bulunan Bazı Alabalık Çiftliklerinin Kuluçkahanelerinde Bakteri Kontaminasyonu ve Bakterilerin Antibiyotik Direncinin Belirlenmesi

Öz: Bu çalışma, Türkiye'nin Doğu Karadeniz bölgesinde bulunan alabalık çiftliklerinin kuluçkahane sistemlerinden izole edilen bakterilerin kontaminasyonu ve antibiyotik direnç profillerini ortaya çıkarmak için yapılmıştır. 11 farklı alabalık çiftliğinin giriş suyu, yumurta, alevin ve yavru örnekleri, dört farklı havzada bakteriyel kontaminasyon açısından incelenmiştir. Örneklemeden sonra izole edilen bakteriler fenotipik ve genotipik analizler yapılarak teşhis edilmiştir. Toplam 43 suşun çoğunluğu Aeromonas ve Pseudomonas cinsinlerine aittir, fakat aynı zamanda Lelliottia sp., Bacillus sp. ve Lactococcus lactis, kuluçka sistemlerinden izole edilmiştir. 2. havza hariç tüm havzalara bakıldığında bakterilerin en yüksek antibiyotik direnci Ampisiline karşı olmuştur. En düşük antibiyotik direnç yüzdeleri gentamisin ve enrofloksasine karşı belirlenmiştir. Araştırma sonucunda, balık çiftliklerinin giriş sularından alınan örneklerde farklı bakterilerin tespiti, kuluçkahane suyunu farklı bakterilerin kontamine ettiğini göstermiştir. Böylelikle bu çiftliklerde hijyen önlemlerinin iyileştirilmesi ihtiyacı belirlenmiştir.

Anahtar kelimeler: Antibiyotik, bakteri, alabalık, kuluçkahane

How to Cite

Kayıs Ş, Soyköse G, İpek ZZ, Er A. 2021. Determination of Bacterial Contamination and Antibiotic Resistance of the Bacteria in the Some Trout Farm Hatcheries in the Eastern Black Sea Region of Turkey. LimnoFish. 7(2): 101-107. doi: 10.17216/LimnoFish.827718

\section{Introduction}

The trout farming in Turkey was grown rapidly due to the technical and scientific advances occurred in the aquaculture and increased demand. Nowadays, trout farming can be done in land-based concrete and soil pools, as well as in net cages in sea, dams, lakes, and ponds. In Turkey, the rainbow trout (Oncorhynchus mykiss), the brook trout (Salvelinus fontinalis) and the Black Sea trout (Salmo sp.) are widely grown species. The trout production was approximately 44.553 tonnes in the year 2000 but reached about 109.657 tonnes in 2017, increasing the amount of production more than a hundred percent in 17 years. It takes place on the first with the largest production among the cultivated species in Turkey (Gün and Kızak 2019). 
Rize is located in the Eastern Black Sea Region of Turkey (Figure 1). The most prominent livelihood of the city is tea agriculture and agricultural products. Besides agriculture, fishing has an important place in the city due to the city's seashore. Rize has a mountainous structure covered with the forest areas. Therefore, the annual average of areal precipitation in the region is higher than the country average and because of these reasons; Rize is also an affluent city in water resources (Gedik et al. 2010).

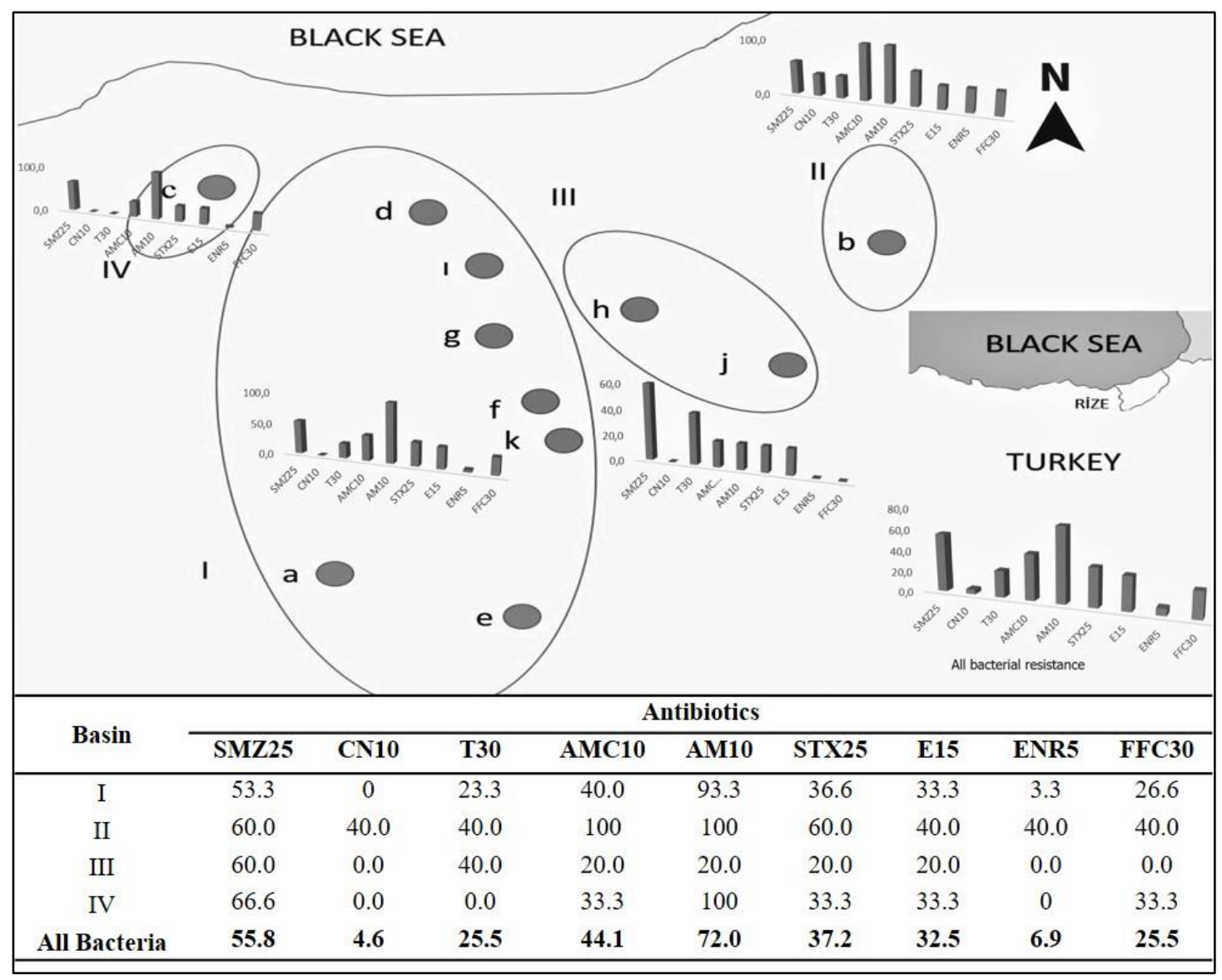

Figure 1. Study area, four different basins and antibiotic resistances of the bacteria (\%). Ampicillin (AM, 10 $\mu \mathrm{g})$,

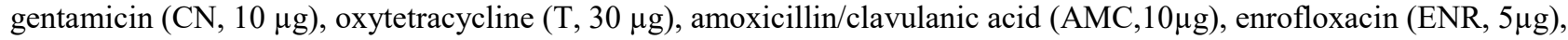

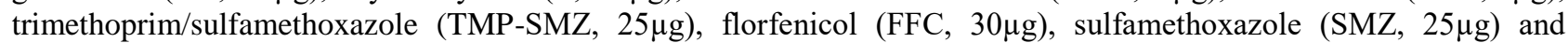
erythromycin $(\mathrm{E}, 15 \mu \mathrm{g})$

In this context, it is known that there are 40 registered fish farming facilities in Rize, 34 of which have hatcheries. Some of these farms have impossibilities arising from small production capacities, lack of technical staff and some of them are family businesses. For these reasons, proper disinfection cannot be performed during the fertilization and incubation periods of the fish eggs. Although the failure to carry out disinfection processes in hatcheries is not considered an economic loss by the owners, this situation will cause economic damage to the business regarding the future mass losses. Moreover, disinfection must be carried out since it is known that it may affect other facilities producing in the same source and biome in the water source (Kayış 2019).

Common pathogens in trout incubation systems are viruses (IPNV, VHSV) (Ișıdan 2006; Yılmaz et al. 2011), fungi (Saprolegnia sp. and Saprolegnia parasitica) (Ural et al. 2011), usually protozoan parasites (Ichthyophthirius multifilis, Trichodina sp., Ichthyobodo necator, etc.) (Balta et al. 2008), and bacterial pathogens (Flavobacterium psychrophilum, Renibacterium salmoninarum, Aeromonas hydrophila, Pseudomonas spp., Yersinia ruckeri, Lactococcus garviae). Flavobacterium psychrophilum and $R$. salmoninarum have been reported as bacteria isolated from hatchery systems (Evelyn et al. 1986; Brown 1997). However, experimental studies have been conducted with A. hydrophila, Pseudomonas spp. and $Y$. ruckeri, various diseases have been reported in the contamination of these bacteria with eggs. Kayış et al. (2014) have provided contamination to the healthy trout eggs of the mentioned bacteria and reported that Pseudomonas species caused sac deformations and $L$. garviae caused haemorrhages in the alevins and juveniles. In another study in which A. hydrophila was contaminated with eggs belonging to $O$. mykiss and 
S. fontinalis, pathogenicity was investigated from the egg stage to the larval stage. In the study, A. hydrophila was reported to cause of blue sac disease and severe mortality in fish (Kayış et al. 2015).

\section{Materials and Methods}

In this study, a total of 5 samplings were carried out between November 2016 and April 2017 from 11 different trout farms in Rize. Egg, alevin and fry individuals of 3 different trout taxa sampled (O. mykiss, Salmo sp. and S. fontinalis) and the inlet water samples of these farms were used. For this purpose, different fish farms in four different basins were selected in Rize. The locations of the farms in the basins are given in Figure 1.

Sterilized $10 \mathrm{ml}$ of glass tubes were used for water samples. At the same time, eggs, alevin and fry samples were sampled with $10 \mathrm{ml}$ sterile glass tubes in each farm. The water temperatures and $\mathrm{pH}$ values of each farm sampled were recorded (Isolab portable $\mathrm{pH}$ and temperature measuring device). In the samples, Tryptic Soy Broth (TSB) and Tryptic Soy Agar (TSA) (Merck) were used as a medium to detect the presence of bacteria, and Anacker Ordal Broth (AOB) medium was used to detect bacteria of the genus Flavobacterium. Also, Glutamate Starch Phenol Red (GSP) Agar was used to distinguish bacteria belonging to the genus Aeromonas and Pseudomonas (Austin and Austin 2007).

All of the samples obtained from the farms were cultured in TSB and AOB media to determine bacterial contamination. Then, TSA medium was used to purify cultures (Lasee 1995). Also, TSA medium was used mostly for the primary cultivation of alevin and fry samples.

The colony shape and colours of bacteria were examined with Gram staining, motility, oxidase, and catalase tests. Colonies forming yellow and purple colours in GSP Agar were considered to be Aeromonas and Pseudomonas, respectively (Cappuccino and Sherman 1992). Hence, an antibiogram test was performed to determine the antibiotic resistance and sensitivity of the isolated bacteria. The pure cultures obtained were stored in tubes containing glycerol at $-80^{\circ} \mathrm{C}$.

Isolated Gram-negative bacteria were cultured in TSB medium for DNA isolation and centrifuged at $3800 \times \mathrm{g}$ for 6 minutes. $100 \mu \mathrm{l}$ of distilled water was added to the pelleted part in the Eppendorf tubes and boiled for 10 minutes at $100^{\circ} \mathrm{C}$. Then after, it was centrifuged at $10000 \times \mathrm{g}$ for 2 minutes, and the supernatant was stocked at $-20^{\circ} \mathrm{C}$. For Gram-positive bacteria, DNA isolation kit (Qiagen, Netherlands) was used. The specific universal primers (27 F 5 'AGA GTT TGA TCC TGG CTC AG-3', 1492 R 5 'GTT TAC CTT GTT ACG ACT T-3') were used for the 16S rRNA region, for the genetic identification of bacteria. As a result of the PCR process, the 1465-bp-length products obtained were purified with the NucleoSpin PCR purification kit (Macherey-Nagel) and sent to the sequence (ABI PRISM 310 genetic analyzer, Applied Biosystems). The results were compared with the sequences available in the National Center for Biotechnology Information (NCBI).

Different antibiotics including ampicillin

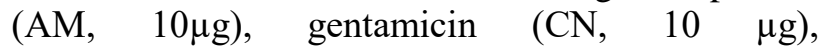
oxytetracycline $(\mathrm{T}, 30 \mu \mathrm{g})$, amoxicillin/clavulanic

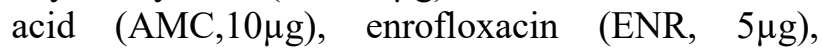
trimethoprim/sulfamethoxazole (STX, 25 $\mu$ g), florfenicol (FFC, 30 $\mu$ ), sulfamethoxazole (SMZ, $25 \mu \mathrm{g})$ and erythromycin $(\mathrm{E}, 15 \mu \mathrm{g})$ were used for determination of the bacterial resistances. Determination of the antibiotic resistance, bacteria inoculated on TSA medium. After then, the colonies on the TSA medium transferred to Mueller Hinton Agar medium. The density of the bacteria was determined as the McFarland 0.5 standard. All process was carried out aseptically according to Clinical and Laboratory Standards Institute (CLSI 2018) guidelines. Antibiotic discs placed on the medium with bacteria and the plates were incubated at $22 \pm 2^{\circ} \mathrm{C}$ for $18-36 \mathrm{~h}$. The resulting zone diameters were recorded as resistant (R) or sensitive (S), according to CLSI (2018) directive.

\section{Results}

The bacterial species identified after cultured from the samples taken from the farms were given in Table 1. Bacteria belonging to the genus Aeromonas and Pseudomonas were generally found in the inlet waters of the farms. Lelliottia spp. were only isolated from one farm. No Flavobacterium spp. were found in any fish farms. It was observed that bacteria isolation was highest in fry individuals (16 strains). The total number of bacteria isolated was recorded as 43 , consisting of intake water (9 strains) and eyed eggs (8 strains), fertilised eggs (6 strains) and alevin (4).

When examined on basin basis, $\mathrm{pH}$ values average I, II, III and IV were measured as 6.79, 5.8, 6.2, and 6.29, respectively. In the first basin, the lowest $\mathrm{pH}$ value was recorded in the farm (1) with 5.7, while the highest value was recorded in the farm (e) with 7.2. In the basin, average temperature value was measured as $9.01^{\circ} \mathrm{C}$. The only farm in the $2 \mathrm{nd}$ basin, the water temperature was $5^{\circ} \mathrm{C}$, and the $\mathrm{pH}$ value was 5.8. The average water temperature and $\mathrm{pH}$ values of the farms in the $3 \mathrm{rd}$ 
basin were recorded as 6.2 and $10.5^{\circ} \mathrm{C}$, respectively. In the farm located in the last basin, the water temperature was recorded as $10^{\circ} \mathrm{C}$ and the $\mathrm{pH}$ value was 6.29.

Table 1. Isolated bacteria and their hosts/samples. (B) basin, (F) farm, (IW) inlet water, (FE) fertilised egg, (EE) eyed egg.

\begin{tabular}{|c|c|c|c|c|c|c|c|}
\hline B & $\mathbf{F}$ & Bacteria & Fish/Samples & IW & FE & EE & Alevin \\
\hline \multirow[t]{24}{*}{ (I) } & $\mathbf{a}$ & ${\text { Lelliottia } \text { sp. }^{1}}^{1}$ & Water & + & & & \\
\hline & & Pseudomonas sp. ${ }^{2}$ & Salmo sp. & & & + & \\
\hline & & Aeromonas tecta ${ }^{3}$ & Salmo sp. & & & & \\
\hline & & Aeromonas sobria ${ }^{4 \mathrm{a}, \mathrm{b}}$ & O. mykiss/Salmo sp. & & & & \\
\hline & & Shewanella sp. ${ }^{5}$ & Salmo sp. & & & & \\
\hline & d & Aeromonas sobria ${ }^{6}$ & O. mykiss & & + & & \\
\hline & & & Salmo sp. & & + & & \\
\hline & & & S. fontinalis & & + & & \\
\hline & $\mathbf{e}$ & Pseudomonas sp. ${ }^{7}$ & O. mykiss & + & & + & \\
\hline & & Pseudomonas fluorescens ${ }^{8}$ & O. myksis & & & & \\
\hline & & Aeromonas sp. ${ }^{9}$ & O. mykiss & & & + & \\
\hline & & Aeromonas sobria ${ }^{10}$ & O. myksis & & & & \\
\hline & & Aeromonas hydrophila ${ }^{11}$ & Water & + & & & \\
\hline & $\mathbf{f}$ & Aeromonas encheleia $^{12}$ & Salmo sp. & & + & & \\
\hline & & Pseudomonas sp. ${ }^{13}$ & O. mykiss/Salmo sp & & & & \\
\hline & $\mathbf{g}$ & Pseudomonas sp. ${ }^{14}$ & Salmo sp. & & & + & + \\
\hline & & Aeromonas encheleia $^{15}$ & Water & + & & & \\
\hline & & Aeromonas sp. ${ }^{16}$ & Salmo sp. & & & & \\
\hline & $\mathbf{1}$ & Aeromonas sobria ${ }^{17}$ & Water & + & & & \\
\hline & & Pseudomonas sp. ${ }^{18}$ & & + & & & \\
\hline & $\mathbf{k}$ & Aeromonas hydrophila ${ }^{19 \mathrm{a}, \mathrm{b}}$ & Water/O. mykiss & + & & & \\
\hline & & (2) & Salmo sp. & & & & \\
\hline & & Aeromonas encheleia ${ }^{20}$ & & & + & & \\
\hline & & Bacillus sp. ${ }^{21}$ & Salmo sp. & & & & \\
\hline \multirow[t]{4}{*}{ (II) } & b & Aeromonas tecta ${ }^{22}$ & O. mykiss & & & + & \\
\hline & & Pseudomonas sp. ${ }^{23}$ & $\begin{array}{c}\text { S. fontinalis/O. } \\
\text { myksis }\end{array}$ & & & ++ & \\
\hline & & Aeromonas tecta ${ }^{24}$ & Salmo sp. & & & + & \\
\hline & & Lactococcus lactis ${ }^{25}$ & O. mykiss & & & & + \\
\hline \multirow[t]{4}{*}{ (III) } & $\mathbf{h}$ & Aeromonas sp. ${ }^{26}$ & O. mykiss/Water & + & & & \\
\hline & & Arthrobacter sp. ${ }^{27}$ & O. mykiss & & & & \\
\hline & $\mathbf{j}$ & Aeromonas tecta ${ }^{28}$ & Water & + & & & \\
\hline & & Pseudomonas sp. ${ }^{29}$ & O. mykiss & & & & \\
\hline \multirow[t]{3}{*}{ (IV) } & c & Aeromonas hydrophila ${ }^{30}$ & Salmo sp. & & + & & \\
\hline & & Pseudomonas fluorescens ${ }^{31}$ & O. mykiss & & & & + \\
\hline & & Enterobacteriaceae bacterium $^{32}$ & O. mykiss & & & & + \\
\hline
\end{tabular}

Accession number of the bacteria; ${ }^{1} \mathrm{~W} 295477,{ }^{2} \mathrm{MW} 295473,{ }^{3} \mathrm{MW} 295469,{ }^{4 \mathrm{a}} \mathrm{MT} 730017,{ }^{4 b} \mathrm{MT} 730018,{ }^{5}$ Shewanella $\mathrm{sp}$. , ${ }^{6} \mathrm{MW} 295496,{ }^{7} \mathrm{MW} 295465,{ }^{8} \mathrm{MW} 295475,{ }^{9} \mathrm{MW} 295494,{ }^{10} \mathrm{MW} 295496,{ }^{11} \mathrm{MW} 295479,{ }^{12} \mathrm{MW} 295468,{ }^{13} \mathrm{MW} 295473$, ${ }^{14} \mathrm{MW} 295475,{ }^{15} \mathrm{MW} 295485,{ }^{16} \mathrm{MW} 295489,{ }^{17} \mathrm{MW} 295496,{ }^{18} \mathrm{MW} 295488,{ }^{19 \mathrm{a}} \mathrm{MT} 730015,{ }^{196} \mathrm{MT} 730015,{ }^{20} \mathrm{MW} 295486$, ${ }^{21} \mathrm{MW} 295490,{ }^{22} \mathrm{MW} 295467,{ }^{23} \mathrm{MW} 295465,{ }^{24} \mathrm{MW} 295467,{ }^{25} \mathrm{MW} 295471,{ }^{26} \mathrm{MW} 295482,{ }^{27} \mathrm{MW} 295493,{ }^{28} \mathrm{MW} 295484$, ${ }^{29} \mathrm{MW} 295492,{ }^{30} \mathrm{MT} 730013,{ }^{31} \mathrm{MW} 295475,{ }^{32} \mathrm{MW} 295476$.

The gas problem was observed in $O$. mykiss fry infected with A. sobria bacteria taken from samples belonging to the one farm (farm a). Also, deformities were found in the individuals of the same fish species infected with Pseudomonas sp. (Figure 2).

Considering all basins, except for the 2nd basin, the highest antibiotic resistance of bacteria was against Ampicillin. The lowest antibiotic resistance percentages were determined against gentamicin and enrofloxacin. The antibiotic resistances of the bacteria are given in Figure 1. 


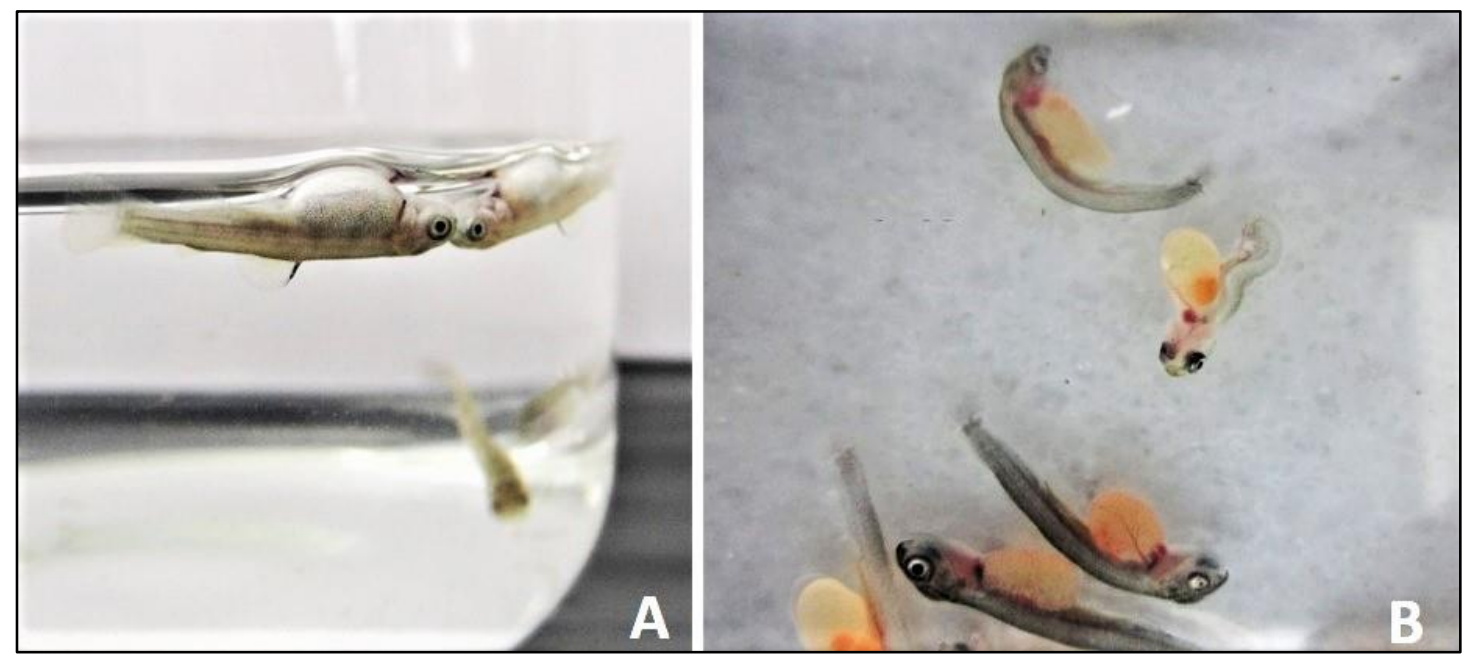

Figure 2. The gas problem infected with A. sobria (A) and deformations infected with Pseudomonas sp. on O. mykiss (B) sampled from (a) farm located in basin (I).

\section{Discussion}

In aquaculture, water quality is a very decisive criterion among different criteria such as fish, feed, personnel and transportation. In many countries, reports are requested for the physicochemical values of water to be used in fish farms. An assessment of the microbiological quality of water is not generally required in these application guidelines. However, previous studies have revealed the necessity of microbiological examination of the inlet waters of fish farms. In this sense, it has been reported that A. salmonicida, A. hydrophila and A. sobria species are isolated from the inlet water from different fish farms belonging to the Black Sea Region of Turkey (Onuk et al. 2017). Similarly, in the present study, different species belonging to the genus Aeromans were found in the inlet water in 6 of 11 farms. Also, Pseudomonas sp. and Lelliottia sp. were found in the inlet water samples.

The presence of bacteria belonging to the genus Aeromonas and Pseudomonas are frequently reported in all aquatic systems worldwide (Hanninen and Siitonen 1995; Fiorentini et al. 1998; Gavriel et al. 1998; Mena and Gerba 2009). In this respect, it is normal to isolate the bacteria belonging to these species from aquatic organisms and many foods. Among bacterial fish pathogens, motile Aeromonas species (A. hydrophila, A. cavia, A. sobria, A. media) and $A$. salmonicida, which is a furunculosis disease agent, have been reported from many fish species worldwide. The pathogenic species of bacteria of the genus Pseudomonas in fish continue to be included in the literature with a new one every day (Altınok et al. 2006; Altınok et al. 2007). This shows that the elimination of these pathogens in trout farming systems is an application that will play a key role in preventing future losses. In this context, the isolation of species belonging to Aeromonas and
Pseudomonas genus in almost every farms in addition to the inlet water in eggs, alevin and fry samples in the farms sampled in the study presented may cause severe mortalities that may occur. Another threat is that bacteria are mostly isolated from fry samples. This also shows that contamination of the mentioned bacteria occurred during the cultivation process.

In general, many Lactococcus species bacteria are isolated from plant origins. The bacteria belonging to the genus Bacillus are generally isolated from the soil. On the other hand, they can be found in the normal flora of vegetables, water and some other live species (Barrie et al. 1994). The genus Lelliottia has been frequently reported, mostly from plant organisms. It can be stated as a common result that these bacteria were isolated from different farms in the samples of inlet water, alevin and fry in this study. Considering the origins of these bacteria, their vegetative, aquatic or soil origin make it natural to have the possibility of contamination to incubation systems. However, looking at the fish disease records of these genera, the genus Lactococcus is a severe disease factor especially with $L$. garviae species. Also, Bacillus mycoides emerges as the causative agent of the disease isolated from sturgeon and it is characterized by gas syndrome in fish in Turkey (Kayış et al. 2017). The genus Lelliottia can be considered as a genus whose pathogenicity should be investigated in fish diseases. The fact that some of the bacteria isolated are of vegetable origin suggests that measures should be taken to prevent plant origin contamination to the incubation systems.

Water quality criteria are important factors for the virulence of pathogenic fish disease factors. For example, $F$. psychrophilum causes disease in fry individuals at temperatures level below $10^{\circ} \mathrm{C}$. On the other hand, Flavobacterium columnare shows 
efficiency at water temperatures of $10^{\circ} \mathrm{C}$ and above. When this study presented is examined in this respect. However, Anacker Ordal media a selective medium for Flavobacterium species, was used, no bacteria belonging to the Flavobacterium genus were found in the samples. This situation can be explained by the fact that water temperature values were 6.5 and $5^{\circ} \mathrm{C}$ in two farms while temperature was $10^{\circ} \mathrm{C}$ and/or above in other farms.

Resistance against antibiotics of bacteria isolated from aquaculture basins has been revealed in many studies. Antibiotic resistance in bacteria is expressed as natural or acquired. Due to the drugs used for the treatment of diseases, the level of resistance increases in bacteria that have taken place in the environment. In this study, the highest antibiotic resistance was determined against ampicillin. This can be explained by the natural resistance of Gram-negative bacteria to ampicillin. Also, the lowest antibiotic resistance was determined against gentamicin. This antibiotic is the most effective on Gram-negative aerobic bacteria (Gür 1996). We determined about $40 \%$ resistance of the bacteria isolated in the 2nd basin against this antibiotic. Lactococcus lactis was the only gram-positive bacteria isolated from all basins. Therefore, there was a resistance to gentamicin in this basin. Also, the low resistance to ampicillin in the 3rd basin can be explained by the same reason.

As a result of the present study, detection of different bacteria in the samples taken from the inlet water of fish farms showed that the water was contaminated. For this reason, before fish farms are established, it can be recommended that they obtained microbiological analysis in the water source they intend to use. It can be thought that the analysis to be made will guide the detection of pathogens in the water and the determination of the measures to be taken. Instead of many microbiologically contaminated hatcheries in different basins, an equipped hatchery can be established to for facilitating microbiological contamination. Increasing bacterial pathogens in terms of quality and quantity of eggs, alevin and fries have shown inadequacy of hygiene measures in aquaculture facilities. In this context, fish farms should review their hygiene measures and follow this issue with a more effective process. Different levels of resistance to antibiotics in different basins are due to bacterial diversity and contamination. For this reason, the veterinary opinion should be taken on the use of antibiotics, and appropriate antibiotics should be used against the target bacteria.

\section{References}

Altınok İ, Kayış Ş, Çapkın E. 2006. Pseudomonas putida infection in rainbow trout. Aquaculture. 261(3):850-855.

doi: 10.1016/j.aquaculture.2006.09.009

Altınok İ, Balta F, Çapkın E, Kayış Ş. 2007. Disease of rainbow trout caused by Pseudomonas luteola. Aquaculture. 273(4):393-397. doi: $10.1016 / j$.aquaculture.2007.10.025

Austin B, Austin DA. 2007 Bacterial fish pathogens: diseases of farmed and wild fish, 4. Edition Springer Publishing, New York, 545p.

Balta F, Kayış Ş, Altınok İ. 2008. External protozoan parasites in three trout species in the Eastern Black Sea region of the Turkey: intensity, seasonality, and their treatments. B Eur Assoc Fish Pat. 28(4):157-162.

Barrie D, Hoffman PN, Wilson JA, Kramer JM. 1994. Contamination of hospital linen by Bacillus cereus. Epidemiol Infect. 113(2):297-306. doi: $10.1017 / \mathrm{s} 0950268800051724$

Brown LL, Cox WT, Levine RP. 1997. Evidence that the causal agent of bacterial cold-water disease Flavobacterium psychrophilum is transmitted within salmonid eggs. Dis Aquat Organ. 29:213-218. doi: 10.3354/dao029213

Cappuccino JG, Sherman N. 1992. Microbiology, A Laboratory Manual, 3rd ed. New York, the USA: Rockland Community College, Suffern 76 p.

CLSI 2018. Clinical and Laboratory Standart Institute. Methods for Dilution Antimicrobial Susceptibility Tests for Bacteria that Grow Aerobically. Wayne, the USA: Clinical and Laboratory Standart Institute $112 \mathrm{p}$.

Evelyn TPT, Prosperi-Porta L, Ketcheson JE. 1986. Experimental intra-ovum infection of salmonid eggs with Renibacterium salmoninarum and vertical transmission of the pathogen with such eggs despite their treatment with erythromycin. Dis Aquat Organ. 1(3):197-202. doi: 10.3354/DAO001197

Fiorentini C, Barbieri E, Falzano L, Matarrese P, Baffone W, Pianetti A, Katouli M, Kühn I, Möllby R, Bruscolini F, Casiere A, Doneli G. 1998. Occurrence, diversity and pathogenicity of mesophilic Aeromonas in estuarine waters of the Italian coast of the Adriatic Sea. J Appl Microbiol. 85(3):501-511. doi: 10.1046/j.1365-2672.1998.853517.x

Gavriel AA, Landre JP, Lamb AJ. 1998. Incidence of mesophilic Aeromonas within a public drinking water supply in North-East Scotland. J Appl Microbiol. 84(3):383-392. doi: 10.1046/j.1365-2672.1998.00354.x

Gedik K, Verep B, Terzi E, Fevzioğlu S. 2010. Fırtına Deresi (Rize)'nin Fiziko-Kimyasal Açıdan $\mathrm{Su}$ Kalitesinin Belirlenmesi. Ekoloji 76:25-35. doi: 10.5053/ekoloji.2010.764 
Gün A, Kizak V. 2019. Dünyada ve Türkiye'de Su Ürünleri Üretiminde İstatistiki Durum. Menba Journal of Fisheries Faculty. 5(2):25-36.

Gür D. 1996. Aminoglikozit antibiyotiklere direnç mekanizmaları ve Türkiye'deki durum. Mikrobiyol Bült. 30:197-204.

Hanninen ML, Siitonen A. 1995. Distribution of Aeromonas phenospecies and genospecies among strains isolated from water, foods or from human clinical samples. Epidemiol Infect. 115(1):39-50. doi: 10.1017/S0950268800058106

Işıdan H. 2006. Önemli Bazı Viral Balık Hastalıkları-II. SÜMAE Yunus Araştırma Bülteni. 6(2):10-13.

Kayış S. 2019. Analysis of Fish Health Status in Terms of Sustainability of Aquaculture in Turkey-A SWOT Analysis. Aquaculture Studies. 19(1):69-76. doi: 10.4194/2618-6381-v19_1_07

Kayış Ş, Mihai PS, Kurtoğlu İ. 2014. Experimental infections of Pseudomonas putida and Pseudomonas fluorescens in rainbow trout (Oncorhynchus mykiss) alevins. El-Cezerî Journal of Science and Engineering. 1(1):7-11.

Kayış Ş, Er A, Yılmaz C, Düzgün A, Köse Ö, Kurtoğlu IZ. 2015. Aeromonas hydrophila as a causative agent of blue sac fry syndrome in different trout species. J Fish Dis. 38(12):1069-1071. doi: $10.1111 /$ jfd.12326
Kayış Ş, Er A, Kangel P, Kurtoğlu IZ. 2017. Bacterial pathogens and health problems of Acipenser gueldenstaedtii and Acipenser baerii sturgeons reared in the eastern Black Sea region of Turkey. Iran J Vet Res. 18(1):18-24.

Lasee BA. 1995. Introduction to fish health management, 2nd ed. Wisconsin: U.S Fish and Wildlife Service $139 \mathrm{p}$.

Mena KD, Gerba CP. 2009. Risk assessment of Pseudomonas aeruginosa in water. Rev Environ Contam T. 201:71-115. doi: 10.1007/978-1-4419-0032-6_3

Onuk EE, Tanrıverdi Çaycı Y, Çoban AY, Çiftçi A, Balta F, Didinen BI, Altun S. 2017. Balık ve yetiştirme suyu kökenli Aeromonas izolatlarının antimikrobiyal duyarlılıklarının saptanması. Ankara Üniv Vet Fak Der. 64:69-73. doi: 10.1501/Vetfak_0000002777

Ural MŞ, Çalta M, Celayir Y, Aydın R. 2011. Gökkuşağ1 alabalığ1 (Oncorhynchus mykiss Walbaum 1972) yumurtalarının dezenfeksiyonunda kullanılan bazı kimyasal maddelerin kuluçka parametrelerine etkisi. Biyoloji Bilimleri Araştırma Dergisi. 4(1):37-41.

Yilmaz E, Yilmaz A, Bilgin B. 2011. Alabalık Kuluçkahanelerinde Görülen Önemli Hastalıklar ve Tedavi Yöntemleri. Türk Bilimsel Derlemeler Dergisi. 4(2):37-39. 